\title{
THE INVESTIGATION OF DENSITY CURRENTS AND RATE OF OUTFLOW FROM A SEPTIC TANK
}

\author{
Maciej Pawlak', Mariusz Skiba', Marcin Spychała', Jakub Nieć' \\ 1 Department of Hydraulic and Sanitary Engineering, Poznan University of Life Sciences, Wojska Polskiego 28, \\ 60-637 Poznań, Poland, e-mail: mpawlak@up.poznan.pl; marsp@up.poznan.pl; jniec@up.poznan.pl
}

Received: 2015.06 .22

Accepted: 2015.08.31

Published: 2015.10.01

\begin{abstract}
The aim of the study was to verify the possibility of the existence of preferential flow paths in a septic tank and the effect of using various types of inlet and outlet in this context. Two of the most unfavourable variants of privileged flow paths for different types of inlet and outlet were analysed. The first variant was related to the occurrence of the privileged flow path below the water surface level directly to the outlet and the second variant - to the so-called boiling phenomenon in a septic tank. During the study, the intensity of outflow from the septic tank was measured. The time between successive doses also was measured. These studies were carried out using several inlet and outlet structures combinations. It was observed that by introducing a suitable outlet it is possible to limit and in the case of the particular type of filtering basket - to eliminate the unwanted phenomenon of preferential flow paths after hot water introduction. The phenomenon of boiling in the septic tank may occur due to the introduction of wastewater of higher density containing a higher concentration of the suspension. The effect of cooler water introduction on this phenomenon was not observed. The limitation of the maximum intensity of outflow from the septic tank can be achieved by filtering basket using at the outlet, which increases the flow resistance thanks to the low porosity.
\end{abstract}

Keywords: density current, septic tank, wastewater, rate of outflow.

\section{INTRODUCTION}

In recent years in Poland the dynamic growth of declarations by local government concerning onsite wastewater treatment plants (WTPs) can be observed. These systems are popular in rural areas, where the building of sewerage systems is not recommended for economic and technical reasons. At the end of 2013 the declared onsite WTPs number was approximately 155 thousand [Environmental protection, Central Office of Statistics (GUS), Poland, 2005-2014], and about 125 thousand of these were installed in rural areas [Municipal infrastructure GUS, 2003-2013] (Figure 1). In recent years the annual growth of declared onsite WTPs can be seen in the range of 20-30 thousand.

The septic tank (ST) is usually the first part of the onsite WTP. The purification of wastewater in a ST occurs during the slow flow of wastewater through the tank, mainly thanks to three processes: sedimentation, flotation and fermentation of sludge accumulated at the bottom, and scum floating at a liquid surface.

The temperature in a ST significantly affects the flow velocity and the efficiency of related processes and hence the quality of out-flowing, pre-treated wastewater. In the study described by Łomotowski and Szpindor [1999], the temperature in the ST ranged from $6{ }^{\circ} \mathrm{C}$ to $14{ }^{\circ} \mathrm{C}$. Heidrich and Stańko [2007] reported that in local wastewater treatment devices, such as onsite WTPs, wastewater temperature does not fall below $10^{\circ} \mathrm{C}$, and the air temperature has little effect on the temperature of wastewater in these devices. At air temperatures below $3{ }^{\circ} \mathrm{C}$ the temperature of the wastewater in a device ranges from $10{ }^{\circ} \mathrm{C}$ to $12{ }^{\circ} \mathrm{C}$ and at air more than $3-6{ }^{\circ} \mathrm{C}$, the temperature of the wastewater ranges between $12.1{ }^{\circ} \mathrm{C}$ and $16^{\circ} \mathrm{C}$, while above the air temperature of $6^{\circ} \mathrm{C}$ - wastewater temperature ranges from $16.1{ }^{\circ} \mathrm{C}$ to $18^{\circ} \mathrm{C}$. 


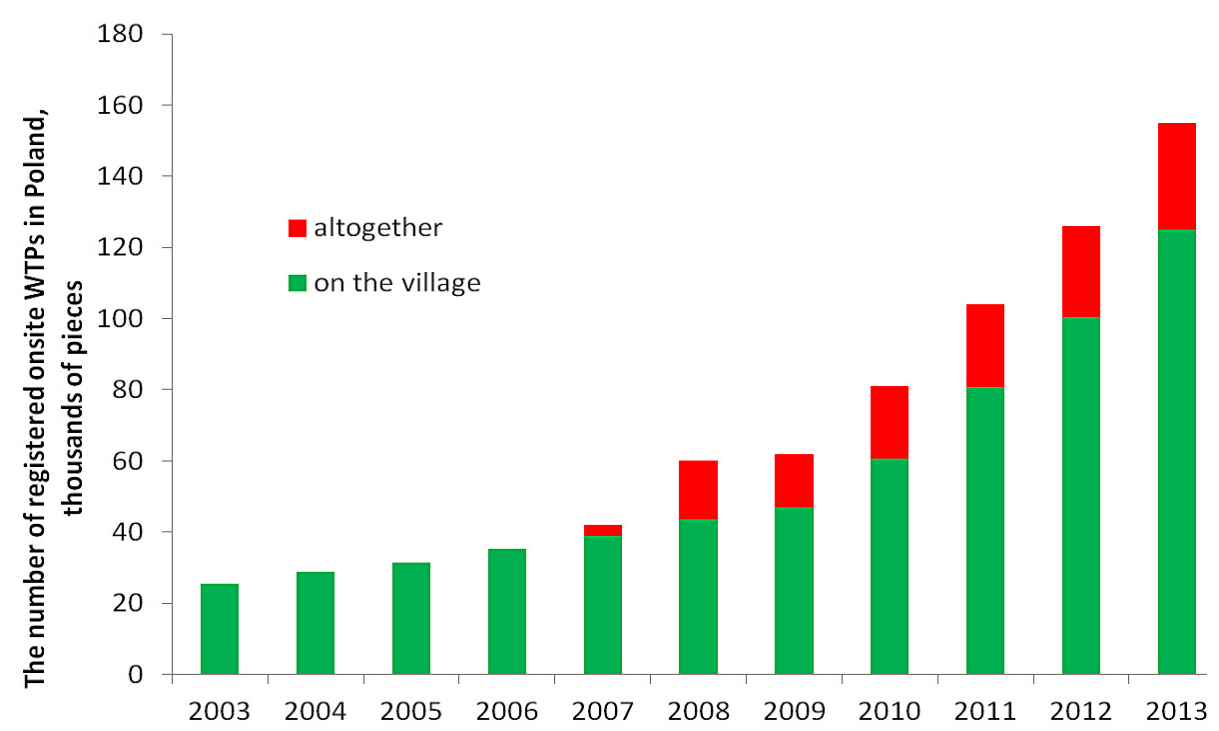

Figure 1. Quantity: the number of reported onsite WTPs by 2013 [GUS 2005-2014]

In contrast, the Matuszewski [2009] study showed a more significant relationship between the temperature of wastewater in the ST at its outflow and air temperature. Figure 2 shows the related temperature dependence in a ST of air temperature (coefficient $\mathrm{R}^{2}$ of linear determination of this dependence is 0.76 ) for a seven-day retention time (comparable to the real wastewater retention time, this ratio was highest and amounted to $\mathrm{R}^{2}=0.82$ ). During the study a minimum temperature of $2.6^{\circ} \mathrm{C}$ and maximum $19.1{ }^{\circ} \mathrm{C}$ was recorded. The temperature of wastewater in a ST below $5{ }^{\circ} \mathrm{C}$ in 2008 was observed 18 times and between $5^{\circ} \mathrm{C}$ and $10^{\circ} \mathrm{C}-158$ times, $10-15^{\circ} \mathrm{C}-$ 83 times, and between $15{ }^{\circ} \mathrm{C}$ and $19.1{ }^{\circ} \mathrm{C}-107$ times. The percentages of occurring temperature ranges are shown in Figure 3.

Research conducted by Matuszewski [2009], as well as data provided by Chmielowski et al. [2009] showed a wider range of temperatures

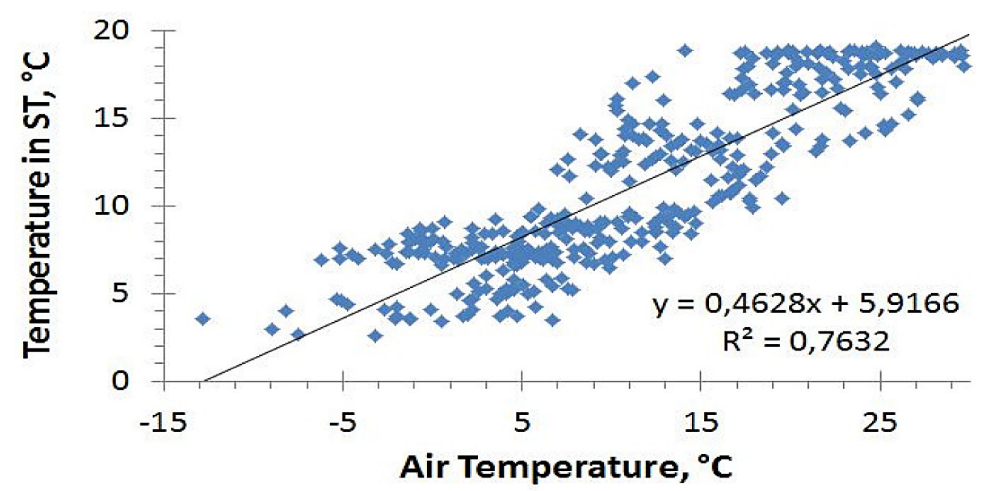

Figure 2. Air temperature and sewage temperature in a ST relation [Matuszeski 2009]

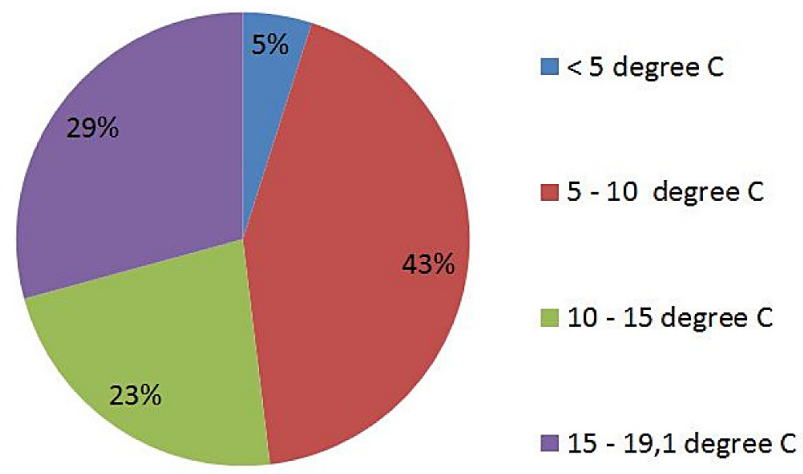

Figure 3. Annual percentage of temperature range in ST wastewater 
found in a ST and a higher effect of air temperature on the wastewater temperature than the data presented by Łomotowski and Szpindor [1999], and Heidrich and Stańko [2007].

A study carried out in North America by Graham showed differentiated wastewater temperatures - from $7{ }^{\circ} \mathrm{C}$ to $22^{\circ} \mathrm{C}$ in the first chamber of the ST and from $2{ }^{\circ} \mathrm{C}$ to $14{ }^{\circ} \mathrm{C}$ in the second chamber at an air temperature between $-20{ }^{\circ} \mathrm{C}$ and $6^{\circ} \mathrm{C}$ [Viraraghavan, 1977], confirming the results of Matuszewski [2009] and Chmielewski et al. [2009]. On the other hand, Bounds [1997] reported that the temperature of wastewater flowing out of ST ranges from $10{ }^{\circ} \mathrm{C}$ to $23{ }^{\circ} \mathrm{C}$. Leverenz et al. [2010] presented the monthly average temperature in a ST in San Francisco (USA), which ranged from about $17^{\circ} \mathrm{C}$ in the period from February to May to $22^{\circ} \mathrm{C}$ in September, while in Quebec City (Canada) - from $9{ }^{\circ} \mathrm{C}$ in January to $22{ }^{\circ} \mathrm{C}$ in July and Kansas (USA) - from $6.5^{\circ} \mathrm{C}$ in April to $18^{\circ} \mathrm{C}$ in August.

In this context, Patterson [2003] studied the temperature of wastewater inside a ST located in Australia, using a 15 minute interval recorder. In his opinion, temperature fluctuations in a ST should be small and short-lasting because of a relatively small volume of hot and cold wastewater in comparison to the volume of the tank. He drew the conclusion that changes in temperature, caused by warm wastewater, e.g. originating from household showering $\left(38^{\circ} \mathrm{C}\right)$ or dishwashers $\left(60^{\circ} \mathrm{C}\right)$ during winter can be substantial and in other seasons - small. He also believes that cold water changes the temperature during the summer, giving the example of a temperature decrease of $1.5^{\circ} \mathrm{C}$ during the period when a large quantity of cold water could be observed, while flushing lavatories and hand washing. During the 14-day period of the four septic temperature study the temperature fluctuations are shown to be in the range of $20-31^{\circ} \mathrm{C}$.

The concentration of the slurry and the temperature have an effect on the density of inflowing wastewater, which, with a high content of suspended solids, behaves as if it had a higher density than the wastewater contained in the ST and indeed had settled on the bottom. As a result, the velocity of the stream is much higher than in theory and the clarifier subsequently has a poorer efficiency. Two possible cases may be related to the influence of the temperature on the density differences. Introducing wastewater into the sump cooler, rather than within it gives rise to a stream bed, which picks up sediments accumulated at the bottom, which occurs especially in summer when cold water is consumed (e.g. flushing of toilets). This relates to the phenomenon known as spring turnover or boil in the septic tank, which may cause deterioration in the quality of wastewater from septic tank effluent. The case where wastewater is warmer (e.g. originating from a bath) causes the creation of a surface stream, especially visible in winter. In this situation, poorly treated wastewater finds a shorter route to the outlet of the septic tank [D'Amato et al., 2008].

Privileged flow path is a problem that occurs in the case of a badly designed settler, incorrect inlet and outlet construction or density currents. Appropriate design can prevent unfavourable density current distribution related to solution inlets and outlets and the geometry of the settlers. Inlets should ensure the equitable distribution of wastewater pathways, the formation of equal liquid streams and the reduction of sludge drift velocity, and that of kinetic energy [Cywiński et al., 1983].

The aim of the study was to verify the theory of the existence of preferential flow paths and the effect of using various types of inlet and outlet in this context.

\section{METHODOLOGY}

Two of the most unfavourable variants of privileged (with using hot and cold water) flow paths for different types of inlet and outlet from the septic tank (option from I to VI) were examined.

The first variant (hot water) was related to the occurrence of the privileged flow path below the water surface level directly to the outlet from the septic tank. The fluid in the septic tank has a temperature of about $2{ }^{\circ} \mathrm{C}$ to about $19{ }^{\circ} \mathrm{C}$ and at $4^{\circ}$ $\mathrm{C}$, the water has the highest density of $1.0 \mathrm{~g} / \mathrm{cm}^{3}$. The incoming water, having a temperature of 38 ${ }^{\circ} \mathrm{C}$ (hot domestic sewage), has a density equal to $0.992993 \mathrm{~g} / \mathrm{cm}^{3}$. Because the water in the septic tank during the experiment was $19^{\circ} \mathrm{C}(0.998430$ $\left.\mathrm{g} / \mathrm{cm}^{3}\right)$, water of $44^{\circ} \mathrm{C}\left(0.990658 \mathrm{~g} / \mathrm{cm}^{3}\right)$ was supplied into the septic tank so as to maintain the same difference in density. The volume of water was about $60 \mathrm{dm}^{3}$, the dosing time 3 minutes. The inflow rate into the septic tank was $0.3 \mathrm{dm}^{3} / \mathrm{s}$.

The second variant (cold water) was related to the so-called boiling phenomenon in the septic tank. The experiment was conducted under 
the same conditions, but the supplied water was about $14{ }^{\circ} \mathrm{C}$. Research was carried out once a day to prevent the conditions in the septic tank from destabilization.

In the study a septic tank with a total volume of $2.3 \mathrm{~m}^{3}$ and active volume of $2.0 \mathrm{~m}^{3}$ was used. During research 45 sensors were installed inside the ST and additional 2 sensors were putted around the inlet and other 3 were placed near the outflow from ST. Distribution of sensors is presented in figure 4.The temperature recording took place every $2 \mathrm{sec}$. The tests were performed in three replications. Table 1 shows the test application options for the inlet and the outlet.

Table 1. The experiment options for the inlet and the outlet

\begin{tabular}{|c|c|c|}
\hline Option & Inlet & Outlet \\
\hline I & A & C \\
\hline II & B & C \\
\hline III & A & D \\
\hline IV & B & D \\
\hline V & A & E \\
\hline VI & B & E \\
\hline
\end{tabular}

During the study also the intensity of outflow from the ST was measured, using a substituted vessel and the time between successive doses (water with a volume of $10 \mathrm{dm}^{3}$ ) was measured.

These studies were carried out according to the following inlet and outlet structures (Figure 5):

A) a classic inlet - a knee of $160 \mathrm{~mm}$ diameter and $90^{\circ}$ angle, with a decompression orifice and extended by a tube of $40 \mathrm{~cm}$ length

B) an inlet with a baffle plate - a knee of $160 \mathrm{~mm}$ diameter and $90^{\circ}$ angle, with a decompression orifice and extended by a tube of $60 \mathrm{~cm}$ length with the notch equal to a half of the circuit
C) outlet - a tee of $110 \mathrm{~mm}$ diameter extended by a pipe of $40 \mathrm{~cm}$ length

D) outlet - a filter basket filled with expanded clay aggregates with a height of $32 \mathrm{~cm}$ and a diameter of $31 \mathrm{~cm}$

E) outlet - a filtering basket (delivered by HABA RL company, filled with plastic carriers) with a height of $108 \mathrm{~cm}$ (long side) and $96 \mathrm{~cm}$ (short side). The inlet is located at a height of $27 \mathrm{~cm}$ from the bottom (shorter side), while the outlet is positioned at a height of $73 \mathrm{~cm}$ from the bottom (shorter side).

\section{RESULTS AND DISCUSSION}

\section{Investigation of flow path of water warmer than the water in the septic tank}

The mean temperature change of the liquid at the time of the outlet of the ST for the six options are shown in Figure 7 (calculated on the basis of 3 repetitions).

- Option I. The sensors just below the water surface showed a significant rise in temperature of about $2.5^{\circ} \mathrm{C}$. The temperature change in time at the outlet of the ST is shown in Figure 6.

- Option II. The warmer water, despite its introduction into the deeper zone, was observed to flow up near the surface. The sensors located at the bottom did not register a change in temperature. A similar situation occurred in the case of sensors installed at half of the height $(0.6 \mathrm{~m})$ of the tank in planes $\mathrm{B}$ and $\mathrm{C}$ in the mid-length of the ST (B) and at the outlet (C). This was related to the fact that hot water, despite its introduction into the deep zone of the tank, flowed to the surface because of its lower
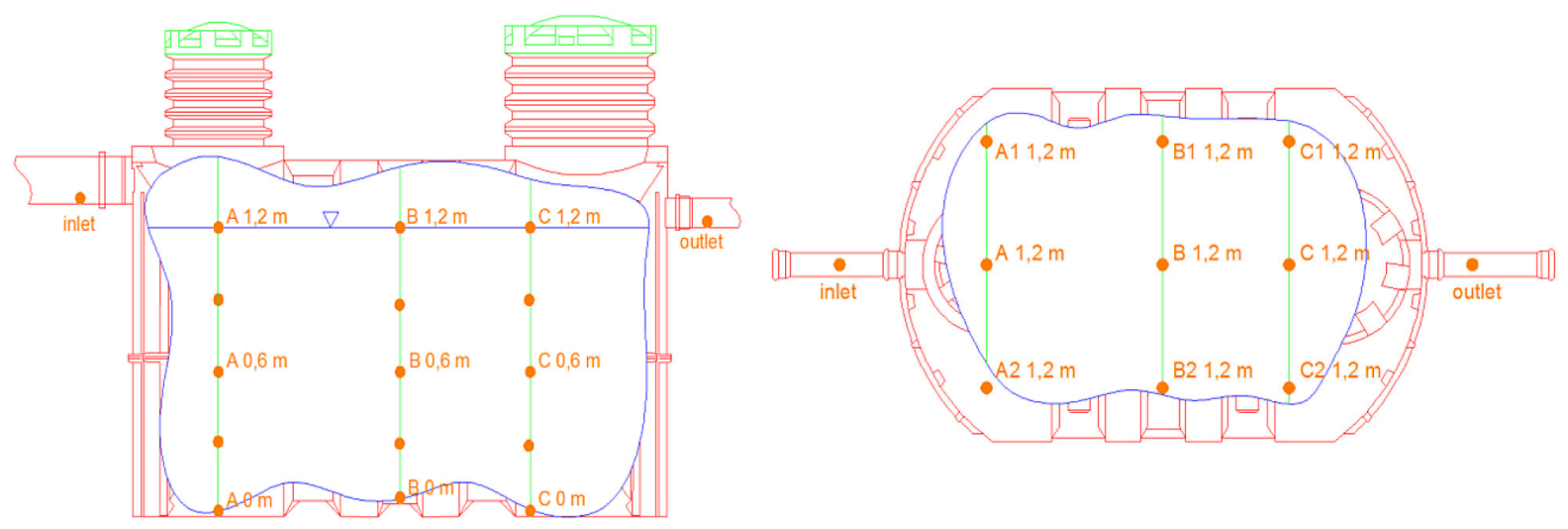

Figure 4. Cross-section of ST and temperature sensors localisation 


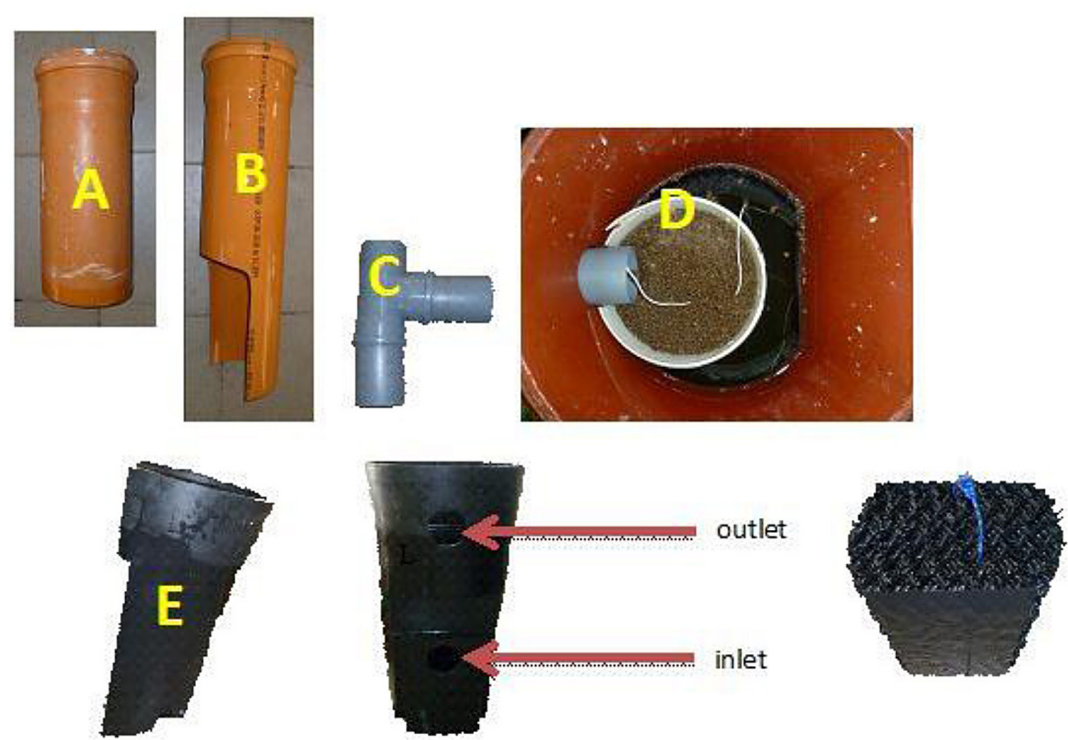

Figure 5. Types of inlet and outlet: A - $160 \mathrm{~mm}$ extension of the tube $40 \mathrm{~cm}$;

$\mathrm{B}$ - an extension of an $160 \mathrm{~mm}$ baffled pipe; $\mathrm{C}-$ a tee $\mathrm{f} 110 \mathrm{~mm}$ inlet pipe extended by $40 \mathrm{~cm}$;

$\mathrm{D}$ - a filter basket filled with expanded clay agregates; $\mathrm{E}$ - Haba's filter basket

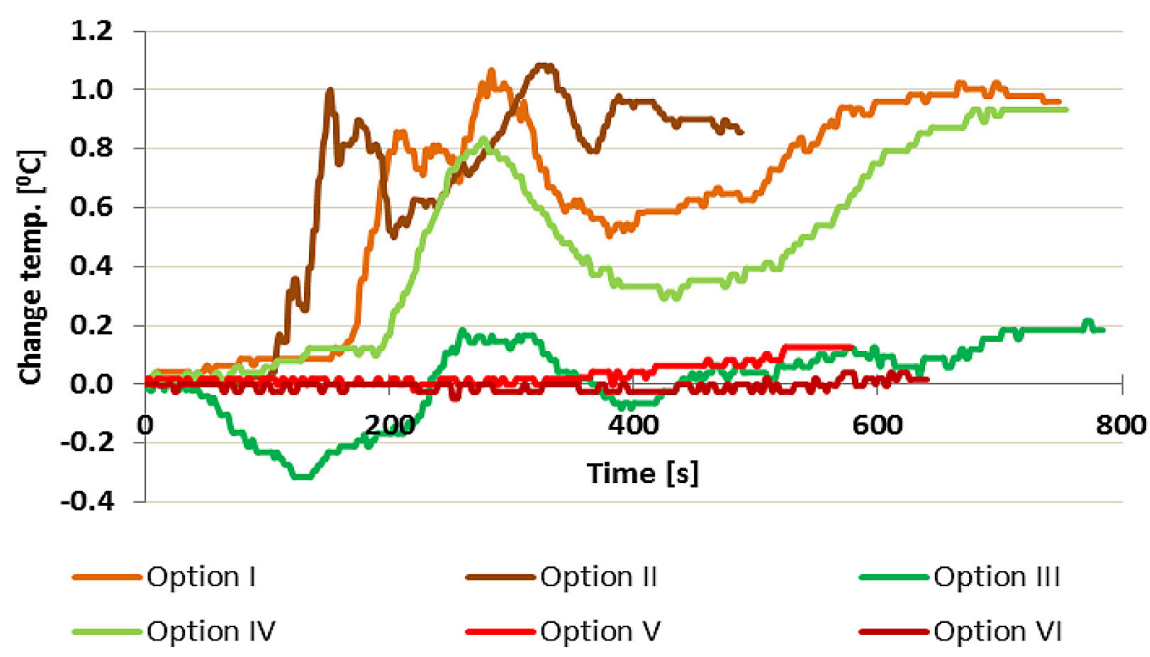

Figure 6. The average temperature of the liquid outflowing from the ST for 6 options

density and turned to the outlet. Sensors located just under the water surface registered considerable changes in temperature of $2{ }^{\circ} \mathrm{C}$, and water temperature in the outlet increased by about $1{ }^{\circ} \mathrm{C}$.

- Option III. Sharp fluctuations in temperature did not appear at the outlet and the temperature trend was growing. The water in the tank is uniformly mixed and the slow outflow thanks to the carriers in the filtering basket resulted in a lack of disturbance at the surface of the water. Practically all the sensors in a close distance to the water surface level showed little change in temperature and the sensor located in the last level (C $1.2 \mathrm{~m}$ ), just below the water surface, showed variations in temperature within $1{ }^{\circ} \mathrm{C}$. The temperature at the bottom and half of the tank height were not subjected to change.

- Option IV. The outlet temperature rose more than $1{ }^{\circ} \mathrm{C}$. The sensors located at the bottom and in the middle of the tank did not register changes in temperature during the entire test. Sensors located just under the water surface registered slight fluctuations in temperature about $0.3{ }^{\circ} \mathrm{C}$.

- Option V and VI. The temperature of the water in the outlet from the ST increased in all six replicates of two tested options by $0.1^{\circ} \mathrm{C}$. The temperature in the other measurement points showed no major fluctuations. At the 
bottom the temperature was constant (about $20^{\circ} \mathrm{C}$ ), while in the mid-height of the tank - the temperature increased by $1{ }^{\circ} \mathrm{C}$. The average temperature of the liquid outflow from the ST for 6 options is shown in Figure 6.

Patterson [2003] stated that the volume of water in the ST is so large that the real inflow of hot water is not expected to cause significant temperature changes. The experiment has shown that this theory needs verification. Despite the large volume of water in the tank after the hot water inflow the temperature varied transiently in the vicinity of the water surface. Hot water after departure from the inlet headed toward the top and flowed near the water surface in the direction of the outlet.

This is due to the fact that hot water rises to the surface due to its lower density. At the bottom of the tank and half of the tank depth, temperature changes were not observed or were negligible. The temperature values being compared and are shown in Table 2. The average temperature difference between initial and maximum was more than $1{ }^{\circ} \mathrm{C}$. In the case of a conventional filter basket mounted at the outlet of the ST, an average difference of $0.3{ }^{\circ} \mathrm{C}$ was observed in the case of a straight (option III) inlet and an average difference of about $1{ }^{\circ} \mathrm{C}$ - in the case of the inlet equipped with the deflector (option IV). This difference wass related to the difference in water application level.

Practically negligible temperature differences were observed in the case of the filtering basket produced by Haba RL filled with a plastic package. This difference was about $0.1^{\circ} \mathrm{C}$ in the case of application of both options of the inlet (A and B). Such a small temperature difference was related to the fact that the inlet to the basket was located very low. Water flowed into the basket at a low level and hot water of lower density accumulated at the water surface, pushing the water of lower temperature into the outlet.

Figure 7 presents average values of temperature differences at the outlet with basic statistical metrics (standard deviation and standard error) for the tested options. Based on statistical analysis it can be assumed that the highest temperature fluctuations occurred in option I and option II. The inlet solution does not have a significant effect on the temperature difference between the liquid before and during the test at the outlet, however the depth (level) of the introduction of hot water has some importance. More important than the depth of the introduction of water itself is the nature of the outlet solution.

\section{Test of preferential flow path of liquid colder than the temperature of ST liquid}

In the case of the application of cold water, the relevant temperature usually does not reach lower than $10-15{ }^{\circ} \mathrm{C}$ and in the ST a maximum of about $20{ }^{\circ} \mathrm{C}$ is observed [Matuszewski 2009, Chmielewski et al. 2009]. In this case, the temperature difference is about $5-10{ }^{\circ} \mathrm{C}$ and in the case of warm water, about $20^{\circ} \mathrm{C}$. During studies using cold water the water inside the tank did not show temperature changes in all options. Only in the interior of the inlet and close to the inlet area was a temperature difference of $1{ }^{\circ} \mathrm{C}$ observed, which encompassed little space and lasted for a short period (fast return to the initial temperature value).

At a temperature difference of several Celsius degrees and a small volume of cold water in comparison to the volume of the tank, the phenomenon of in the ST does not occur due to the temperature

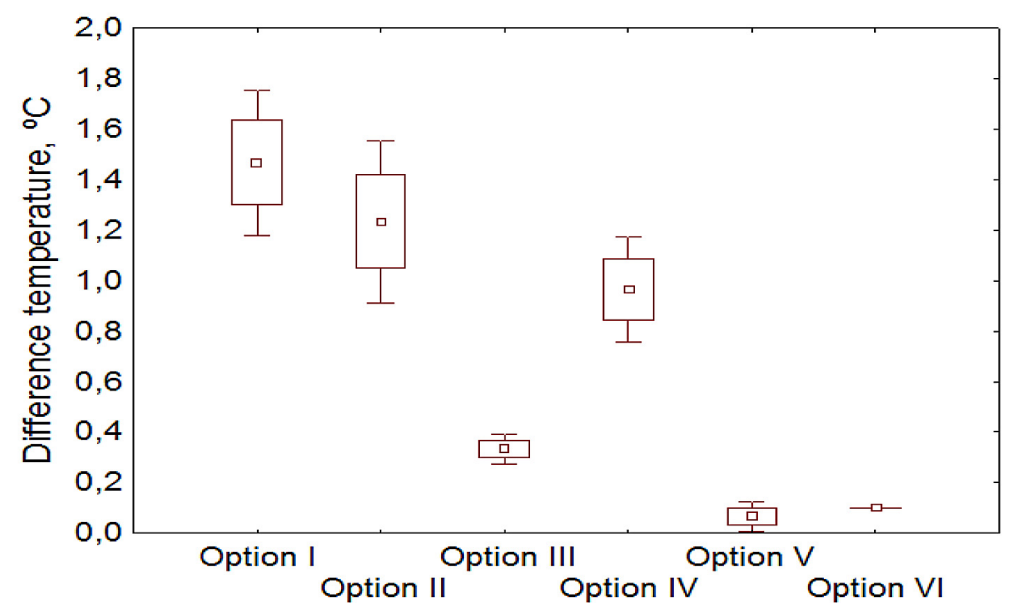

Figure 7. The average values of temperature differences at the outlet with basic statistical metrics 
difference, however, it can be related to the density difference caused mainly by the amount of suspension and additionally, can be supported by the temperature difference.

Patterson [2003] confirmed this thesis, indicating the small volume of introduced liquid (compared to the liquid in the tank) and a small, short-term temperature change caused by the introduction of liquid at various temperatures. Patterson's [2003] studies do not confirm the thesis proposed by D'Amato et al. [2008] suggesting the possibility of in a ST under Polish atmospheric conditions.

\section{The outflow rate from ST}

The flow rate into the tank was always the same and it was about $0.3 \mathrm{dm}^{3} / \mathrm{s}$. Comparing the average flow rates of particular options (Figure 8) we can see the relationship between the types of outlet and the outflow rate, where it was clear that the pairs of curves overlap for each type of outlet prevention system.

The highest flow unitization was provided by a filtering basket filled with expanded clay aggregates (option III and IV) for experiments with cold and warm water. Filling the basket with expanded clay aggregates caused the highest resistance to the out-flowing water. The smallest reduction in flow streams is ensured by the Haba, RL filtering basket (option V and VI) in the case of warm water and in the case of cold water, the maximum outflow was comparable to the flow

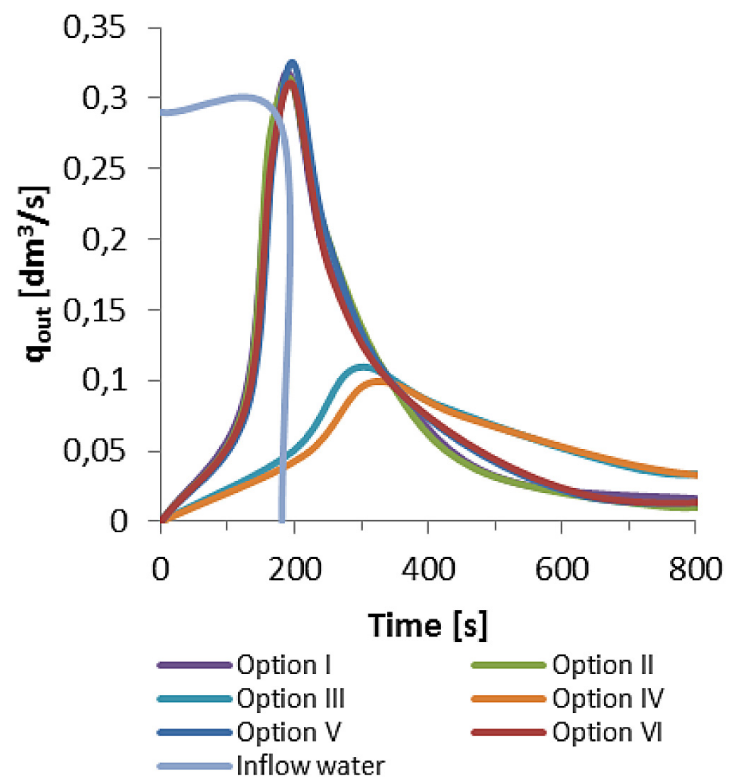

rate of the inflowing liquid. The filling media of the HABA RL basket filter is made of plastic with large pores that do not cause significant resistance to liquid flow.

Thanks to the large height of the filtering basket and an inlet located at the bottom, the water level appeared to rise, causing an increase in flow velocity through the basket. Where there was a tee at the outlet of the ST (option I and II) for the outflow of cold water, the flow was comparable to the option of the HABA RL basket at cold water flow. However, in the case of the hot water the tee-shape outlet (option I and II) reduced the flow rate to the value of $0.20 \mathrm{dm}^{3} / \mathrm{s}$. This value is very close to the value obtained in experiments with a filtering basket filled with expanded clay aggregates for hot water.

Table 2 represents the maximum outflow from ST recorded during the test and the time for the outlet solution options.

\section{CONCLUSIONS}

Laboratory tests allowed to draw the following conclusions:

1. It was observed that by introduction a suitable outlet, it is possible to limit outflow hot water outflow from ST. In the case of using the Haba RL basket - to eliminate the unwanted phenomenon of preferential flow paths through the ST. No effect of the inlet construction on reducing this phenomenon was observed.

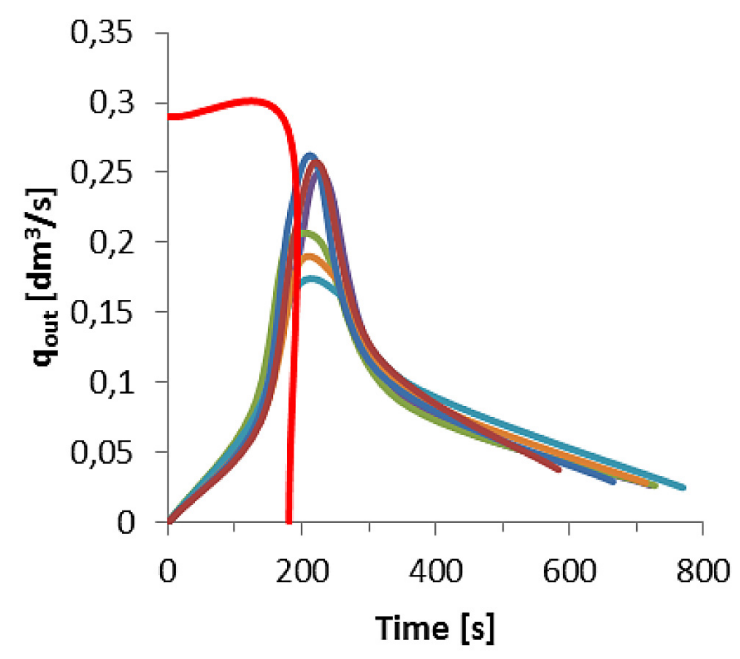

Figure 8. Changes in the average outflow for the six options for hot water (left graph - variant 1) and cold water (right graph - variant 2) 
Table 2. The characteristic values of outflow at different options and two variants

\begin{tabular}{|c|c|c|c|c|}
\hline \multirow{2}{*}{ Option } & \multicolumn{2}{|c|}{ Hot water (variant 1) } & \multicolumn{2}{c|}{ Cold water (variant 2) } \\
\cline { 2 - 5 } & time of outlet [min.] & maximum flow outlet [dm $3 / \mathrm{s}]$ & time of outlet [min.] & maximum flow outlet [dm ${ }^{3} / \mathrm{s}$ ] \\
\hline I & 11.5 & $0.20 \pm 0.003$ & 15 & $0.31 \pm 0.004$ \\
\hline II & 11.5 & $0.25 \pm 0.060$ & 15 & $0.32 \pm 0.037$ \\
\hline III & 12.5 & $0.17 \pm 0.013$ & 25 & $0.11 \pm 0.000$ \\
\hline IV & 12.5 & $0.18 \pm 0.018$ & 25 & $0.10 \pm 0.001$ \\
\hline V & 10 & $0.26 \pm 0.011$ & 16 & $0.31 \pm 0.018$ \\
\hline VI & 10 & $0.26 \pm 0.024$ & 16 & $0.32 \pm 0.018$ \\
\hline
\end{tabular}

2. The cause of the boiling phenomenon in the ST may be the introduction of wastewater of higher density containing a higher concentration of the suspension. The effect of cooler water introduction (due to the small differences and fast equalization of temperatures) on the socalled boiling phenomenon was not observed.

3. The limitation of the maximum intensity of outflow from the ST can be achieved by filling the outlet (e.g. in the form of a basket) with a material of low porosity, which increases the flow resistance and causes a rise in water surface level in the tank. Otherwise, the outflow rate will be comparable to the inflow rate.

\section{REFERENCES}

1. Bounds T.R. 1997. Design and performance of septic tanks. Site Characterization and Design of Onsite Septic Systems ASTM STP 901. M.S. Bedinger, A.I. Johnson, and J.S. Fleming, Eds., American Society for Testing Materials. Philadelphia.

2. Chmielowski K., Wałęga A., Miernik W. 2009. Wpływ temperatury powietrza na temperaturę ścieków w przydomowej oczyszczalni z filtrem piaskowym o przepływie pionowym. Infrastruktura i Ekologia Terenów Wiejskich, 6, 57-65.

3. Cywiński B., Gdula S., Kempa E., Kurbiel J., Płoszański H. 1983. Oczyszczanie ścieków. Oczyszczanie mechaniczne i chemiczne, Arkady, Warszawa.

4. D’Amato V.A., Bahe A., Bounds T., Comstock B., Konsler T., Liehr S K.., Long S. K., Ratanaphruks
K., Rock Ch. A., Sherman K. 2008. Factors affecting the performance of primary treatment in decentralized wastewater systems. Raport WERF 04-DEC-7. Wyd. IWA Pub.

5. GUS. Ochrona środowiska 2005, 2006, 2007, 2008, 2009, 2010, 2011, 2012, 2013, 2014; Warszawa.

6. GUS. Infrastruktura komunalna 2003, 2004, 2005, 2006, 2007, 2008, 2009, 2010, 2011, 2012, 2013; Warszawa.

7. Heidrich Z., Stańko G. 2007. Leksykon przydomowych oczyszczalni ścieków. Wyd. Seidel-Przywecki, Warszawa.

8. Leverenz H.L., Tchobanoglous G., Darby J.L. 2010. Evaluation of greenhouse gas emissions from septic systems. Raport WERF DEC1R09. Wyd. IWA Pub.

9. Łomotowski J., Szpindor A. 1999. Nowoczesne systemy oczyszczania ścieków. Wyd. Arkady, Warszawa.

10. Matuszewski G. 2009. Zależność pomiędzy temperaturą powietrza a temperaturą ścieków w mechaniczno-biologicznych przydomowych oczyszczalniach stosowanych w indywidualnych gospodarstwach rolnych. Maszynopis pracy magisterskiej Uniwersytet Przyrodniczy w Poznaniu KIWiS.

11. Patterson R.A. 2003. Temporal variability of septic tank effluent. In: Patterson R.A. and Jones M.J. (Eds.) Future directions for on-site systems: Best management practice. University of New England, Armidale, Published by Lanfax Laboratories Armidale.

12. Viraraghavan T. 1977. Influence of temperature on the performance of septic tank systems. Water, Air and Soil Pollution, 7, 103-110. 